UDK 378:004]:614.4

37.018 .4

Project review

\title{
THE IMPLEMENTATION OF JEAN MONNET PROJECT ACTIVITIES IN PANDEMIC CONDITIONS: PAINS AND GAINS*
}

\author{
Ljubica Kordić, PhD, Associate Professor \\ Josip Juraj Strossmayer University of Osijek, Faculty of Law \\ Stjepan Radića 13.31000 Osijek, Croatia \\ kljubica@pravos.hr
}

\begin{abstract}
The Faculty of Law Osijek, Josip Juraj Strossmayer University of Osijek, has been granted in the year 2020 a financial support by the European Commission in implementation of the Jean Monnet Module No. 620231-EPP-1-2020-1-HR-EPPJMO-MODULE titled 'Jean Monnet Module Language and EU Law Excellence", Decision No 620231 of September 15, 2020. The project has been elected for financing by the European Commission among almost 1500 project applications from the whole world. Three projects from the Republic of Croatia have been accepted, one of them being the "Language and EU Law Excellence" (LEULEX) project. The project beneficiary is Josip Juraj Strossmayer University of Osijek, and the project holder is the Faculty of Law Osijek. The implementation of the project has started in September 2020 and it will last until September 14, 2023. As the project encompasses teaching activities, events and workshops that were initially planned to be delivered in face-to-face form, the implementation of the project in conditions of the world pandemic of Covid-19 virus has become very challenging and needed adapting of all stakeholders to new conditions. The main goal of this paper is to present the ways, solutions and answers that were offered to these unexpected challenges and to explore how the participants in the project perceive the teaching activities within the project conducted by means of online platforms and tools with reference to improvements achieved in their knowledge and skills within the respective project activity. The method used in the research is a survey administered online among the participants of the Jean Monnet Project LEULEX. In the introductory part of the paper, the author, who is a coordinator and a contact person of the project, presents the Jean Monnet Module LEULEX and defines its main idea, goals and the planned outcomes of the project. The main part of the paper is dedicated
\end{abstract}

This paper is a product of work that has been fully supported by the Jean Monnet Module Language and EU Law Excellence LEULEX, project no. 620231-EPP-1-2020-1-HR-EPPJMO-MODULE. The European Commission's support for the production of this publication does not constitute an endorsement of the contents, which reflect the views only of the authors, and the Commission cannot be held responsible for any use which may be made of the information contained therein. 
to description of the implementation of the project that was adapted to the new Covid-19 pandemic situation. The results of the survey conducted among the project participants relating to implementation of online teaching tools, platforms, and technologies are discussed and andlysed with reference to the outcomes of the project. In the closing part to the paper, conclusions are drawn on benefits and shortcomings of the changed approach to implementation of the project activities in the conditions of the Covid-19 pandemic, which has strongly influenced private and professional lives of the people all around the world.

Keywords: benefits, challenges, distance learning, Jean Monnet Module, teaching conditions

\section{INTRODUCTION}

Because Croatian legal system is an integral part of the supranational law of the European Union as the multicultural and multilingual political and economic community, knowledge of the basics of EU law and mastering the working languages of EU institutions represent indispensable prerequisites for the legal profession and development of the professional career of Croatian lawyers. Since the establishment of European Communities, numerous European documents confirmed the commitment of European institutions to promote multilingualism in Europe and enhance communication skills in modern languages. For example, the Council of Europe Resolution of 1995, and especially the Sorbonne Declaration (1998) encouraged developing programs in higher education that would enable students to develop their language skills necessary for students' mobility within European universities.

\section{JEAN MONNET MODULE "LANGUAGE AND EU-LAW EXCELLENCE”}

In the year 2020, the Faculty of Law developed a Jean Module "Language and EU-law excellence" that was accepted to be financially supported by the European Commission. The undergoing idea of the project was that the students of the Faculty of Law Osijek should improve their knowledge of EU law and master English, German and French in the field of EU law to become more competitive on the labour market and be qualified for new jobs requiring both legal and linguistic knowledge. Accordingly, students of the Translation Section within the English Language and the German Language Studies at the Faculty of Humanities Osijek should be equipped with basic knowledge in EU law and legal terminology to be able to apply for new jobs requiring linguistic skills in the field of EU law. By implementing different types of activities, the project should increase the professional competencies of lawyers and law students on one hand and students and graduates of Foreign Language Studies at the University of Osijek on the other, and make them more competitive on the labour market. 
The project found favour in the European Commission among more than 1440 applications as the first of three Jean Monnet project applications from the Republic of Croatia that were accepted by the European Union. The value of the project is estimated at 30.240,00 Euro, $75 \%$ of which is financed by the European Commission and $25 \%$ by the Faculty of Law Osijek. The beneficiary of the project is J. J. Strossmayer University of Osijek, while the holder of all project activities is the Faculty of Law Osijek. The project team is composed of two professors from the Department of European Law and three professors from the Department of Foreign Languages and Sociology, the Faculty of Law Osijek, three associate members from the Faculty of Humanities and Social Sciences Osijek, as well as the French professor employed at the Comprehensive High School of Osijek. Special thanks for readiness to participate in the project both with its teaching staff and its equipment and licensed teaching tools goes to the dean of the Faculty of Humanities and Social Sciences of Osijek. The project could not have been implemented without their help and cooperation. The implementation of the project has started in September 2020 and will last till the end of August 2023.

\subsection{Basic ideas, goals, and the target group of the project}

The interdisciplinary project Jean Monnet Module "Language and EU-law excellence" is founded on the idea that in the European Union the knowledge of EU law and mastering English, French and German legal terminology are of utmost importance for the successful career of Croatian lawyers. The interconnectedness of law and language has been indisputable for centuries, and this fact was highlighted by many lawyers and linguists. For Paul Kirchhof, law lives in language and through language ("Recht lebt in Sprache und durch Sprache") ${ }^{1}$, and for Otto Gierke language is the body of law (Die Sprache ist nicht nur das Kleid, sondern der wahre Leib des Rechts) ${ }^{2}$.Accordingly, the translation in the field of law, which implies both legal and the linguistic knowledge of the translator, is a very demanding and responsible task: "Legal translation (...) leads to legal effects and may induce peace or prompt war". ${ }^{3}$ Translating legal texts is very important in the functioning of EU institutions and the EU generally, and there are some new jobs and professions in EU institutions and their bodies in the member states that require both the knowledge of EU law and excellence in foreign languages, especially English, French, and German.

Kirchhof, P., Rechtsprechen ist mehr als Nachsprechen von Vorgeschriebenem, in: Haß - Zumkehr, U. (Hrsg): Sprache und Recht, Jahrbuch 2001, W. de Gruyter, Berlin - New York, 2001. pp. 119-135.

2 Gierke, O., Das bürgerliche Gesetzbuch und der deutsche Reichstag. Berlin, 1896.

3 Šarčević, S., Introduction, in: Šarčević, S. (ed.), Legal Language in Action: Translation, Terminology, Drafting and Procedural Issues, Globus. Zagreb, 2009, pp. 9-21. 
That is the reason why this interdisciplinary project aims not only at widening the students' knowledge of EU law but also at developing the awareness of the importance of mastering working languages of EU institutions for Croatian lawyers and translators in conditions of multilingual professional communication worldwide.

The target groups of students are a) law students on the undergraduate, graduate and postgraduate levels, b) graduate lawyers (representatives of non-governmental organizations, civil servants, judges, etc.), c) students of the Translation studies of the Faculty of Humanities and Social Sciences Osijek and the graduates of those Studies and d) young researchers, lawyers and other interested legal professionals from the partner universities in neighboring countries. Upon the fulfillment of all obligations within the project, the attendants receive the certificate of attendance signed by the dean of the Faculty of Law Osijek and the coordinator of the project.

\subsection{Objectives, outcomes, outputs, and the impact of the project}

The Jean Monnet Module "Language and EU-Law Excellence" aims at 1) enhancing foreign language teaching in the field of EU Law - English, French and German, in order to impact positively the mobility of students of the Faculty of Law and to facilitate their speaking and translation skills in the three languages, and 2) at strengthening their proficiency in EU law and its terminology in these three languages, 3) at developing cooperation and interdisciplinary teamwork with the Translation Studies from the Faculty of Humanities of the University of Osijek with an overall idea of developing and promoting excellence in academic and professional achievements of language students in the field of EU law and of the students of law in the field of foreign languages.

General objectives of the project are:

- to mainstream the development of the teaching process and methods of education within the European studies and contribute to their greater visibility at a national and international level;

- to enhance interdisciplinary synergy of students, teachers, and the wider community;

- to promote multilingualism, multiculturalism, and European values in all activities;

- to promote innovation in teaching by including new technologies, media, and methods (this turned out to be a most striking element in carrying out the objectives!);

- to contribute to the promotion and greater visibility of European values and ideas on the international level by attracting attendants from Serbia, Bosnia and Herzegovina, and Northern Macedonia. 
Specific objectives include

- improving students' knowledge on EU Law and promoting EU values by stressing the EU law dimension in all courses,

- improving the knowledge and application of EU Law terminology in English, German and French to impact positively the mobility of students,

- developing students' communication skills in the field of law in the European context,

- developing translation skills in the field of law by using modern translation tools.

The undergoing overall aim of the project was to promote EU law and modern languages in the field of law. This should be achieved by seven teaching activities encompassing 75 hours, four workshops encompassing 12 hours, and four events including one international conference.

The main outputs of the project include the development of an original curriculum with some renewed and some completely new courses (some courses partly lean on the courses developed within the Lifelong Learning Program for Lawyer Linguists). In defining outputs and the impacts of the project, it was necessary to determine in advance which groups of people will benefit from the project. So we predicted the participation of 20 law students per year, 10 students from the Faculty of Humanities per year, 20 lawyers from different fields of legal profession, 10 representatives of the local self-government units and non-governmental organizations and 5-10 young academics from neighbouring countries per year on average 70 participants per year. Beyond expectations, 120 participants joined the project in the first project year. Most of them were law students and graduates from the Faculty of Law, but there were also 22 students and graduates from the Faculty of Humanities (not only of Osijek, but also of Zagreb). 12 participants were researchers from the law faculties in Serbia, Bosnia and Herzegovina, and Northern Macedonia.

The main outcome of the project is defined as reinforcing a European dimension of law studies and translation studies and increasing the competitiveness of future lawyers and translators on the labour market in national and European contexts. The project should also contribute to a modern, dynamic and professional environment at the Faculty by its interdisciplinary approach, by developing innovative curricula and courses, and by applying modern teaching tools and methodologies. While planning the project, we could not imagine how important modern media and online teaching tools and platforms will be for the implementation of the project. 
Due to the unexpected emergence of the Covid-19 pandemic that impacted all the aspects of our private and professional lives, the implementation of project activities was faced with serious challenges, which will be presented in the following chapters.

\section{THE CHALLENGES OF PROJECT IMPLEMENTATION IN PANDEMIC CONDITIONS}

As specified in the introductory part, project activities include teaching, workshops, events and final conference. In the first project year we have organized one promotional event, carried out the planned 75 hours of teaching and delivered four workshops. Due to the Covid-19 situation at the beginning of November 2020, the promotional event was held by hybrid approach with a rather small number of participants present in the Council Hall of the Faculty, while a great majority of participants attended the event via the platform Zoom. In those circumstances, it was impossible to give lectures and workshops as planned by faceto-face approach, so we sent a request to the EC administrator in charge of Jean Monnet Modules and asked for the permission to implement the teaching activities online. At the meeting held online with the representatives of the EC by the end of November, it was decided that distance learning and online platforms can be used as appropriate methodological approach in pandemic conditions.

So instead of being carried out by face-to-face approach, most activities were delivered online, by using the platform Zoom. Following courses were delivered as compulsory courses by using zoom platform exclusively: Legal language and the EU, Basics of EU-Law, Using Parallel Corpora in Translating EU Legislation, and Introduction to EU-Law Terminology - French. The courses EU-Law Terminology and Translation - English and EU-Law Terminology and Translation - German, as well as Modern Translation Tools are offered as elective courses, two of which become compulsory after being chosen by students.

In the two latter elective courses, a hybrid approach was used (a combination of face-to-face approach and distance teaching by using the platform Zoom). The course in German was elected by a rather small group of attendants. The problem was that they entered the course with a very different level of knowledge of that language. Some of them were very motivated to learn as much as possible (students waiting for the Erasmus exchange visit to Germany) and insisted on face-toface teaching, while others have chosen virtual teaching by Zoom, so the professor held the course by hybrid approach. A similar situation concerning the initial knowledge level was a characteristic of the course Introduction to French Legal Terminology. The only teaching approach used in that course was by the Zoom 
platform. Due to great differences in knowledge of French language, students who have never learned French were not able to advance through the course at the same pace with those who have attended the course in foreign languages schools. For them, individual work in a face-to-face approach would be a more efficient way of teaching. The elective course Modern Translation Tools, in which students practice the application of licenced online translation tools available at the Faculty of Humanities (Sketch Engine, TermEx, InterpretBank Software for Conference Interpreters, ApSIC Xbench, Subtitle Workshop, Dragon Naturally Speaking Premium, etc.), was also held in the hybrid form. Accordingly, the workshop on Conference Interpreting was held in hybrid form, with a limited number of students practicing conference interpreting in cabins individually, while others followed what they did in the virtual breakout rooms on the Zoom. Only the workshop on the CATT memo-Q was delivered face-to-face in a group of 14 students because of the limited number of computers with installed licenced memo-Q translation tool available at the Faculty of Humanities. The workshops "Litigation before CJEU" and "Databases and Information on the EU" were carried out by virtual teaching on the platform Zoom.

\section{RESEARCH INTO STUDENT OPINIONS ON ON- LINE PLATFORMS AND METHODS USED IN THE IMPLEMENTATION OF THE PROJECT}

\subsection{Theoretical background}

In pandemic conditions, using information technologies and online teaching tools has become a usual way not only of communication with students but also the dominating method of delivering all the courses. Digital technologies have become, especially in recent conditions of Covid-19 pandemic, an indispensable tool in carrying out teaching activities at all education levels. According to Castro ${ }^{4}$, digital platforms for distance teaching can improve learning-teaching activities a) by providing access to more students and facilitating self-paced online learning activities and b) by offering an individual path of learning for each student, thus improving out-of-class activities and feedback. The implementation of new media in teaching ranges from simple information gathering over distance and blended learning to Internet-based projects. ${ }^{5}$ Research confirmed that blended learning (the combination of online and face-to-face instruction) produces better results

Castro, R.: Blended learning in higher education: Trends and Capabilities, Education and Information Technologies (Springer) volume 24, 2019, pp. 2523-2546 (2019), https://doi.org/10.1007/s10639019-09886-3.

5 Dudeney, G.; Hockly, N. How to Teach English with Technology, Pearson, Essex, 2007. 
in large classes. ${ }^{6}$ The thesis by Ketterer and Marsh, that "the traditional classroom model of instruction is increasingly problematic in the face of new and emerging technologies of instruction"7 are acceptable in a limited sense because many recent studies have shown that students still prefer face-to-face contacts with their teachers. Accordingly, a recent internal survey conducted online at the beginning of the academic year 2020/2021 at the Faculty of Law Osijek revealed that most students preferred attending courses face-to-face (42.7\%), a slightly lower percentage of students $(40.5 \%)$ preferred virtual methods of distance teaching, while $16.8 \%$ said they would prefer the hybrid approach. The courses and workshops of the Jean Monnet Module Language and EU Law Excellence make no exception to that rule. This might have caused more difficulties for teachers who are mostly trained to deliver courses in face-to-face approach than for students, who belong to the generation of "digital natives", growing up surrounded by mobile phones, computers, and virtual social networks. In the given situation, teachers have shown great flexibility and readiness to exploit the opportunities of new media in teaching. In the implementation of the Jean Monnet project LEULEX, the application of modern media was seen not only as an inevitable method of delivering the courses in the conditions of pandemic, but also as a motivating factor and a way of introducing dynamics in the teaching process. Although some authors express "a healthy scepticism" towards the usage of information technologies in delivering courses ("Teachers should have at the same time a positive attitude towards and a healthy scepticism of these technological devices") ${ }^{8}$, they do not deny their motivational role in the modern teaching process. Motivation in teaching is seen as a means of increasing the initiation of activities and of students' persistence in carrying out the tasks. ${ }^{9}$ Information technologies can positively influence both intrinsic and extrinsic motivation and need to be integrated into modern course designs. However, many explorations of students' attitudes towards distance teaching by online platforms have been conclusive that students miss the face-to-face contact with their teachers. This confirms that the teacher has remained an important motivational factor, despite possibilities opened by new media. In terms of results

$6 \quad$ Ketterer, J.; Marsh, G.,. Re-Conceptualizing Intimacy and Distance in Instructional Models, in: Online Journal of Distance Learning Administration, Volume IX, Number 1, 2006, [https://www.westga. edu/-distance/ojdla/spring91/spring91.htm]

7 Ibid.

8 Dudley-Evans, T.; St John, M.J., Developments in English for Specific Purposes, University Press, Cambridge 2007, p. 185.

9 Larson, W. R.; Rusk, N.. Intrinsic Motivation and Positive Development, in: Lerner, R. M.; Lerner, J. V.; Benson, J. (eds.), Advances in Child Development and Behavior, pp. 89-130, Academic Press, Burlington, 2011 
achieved by distance teaching of the large groups of students, recent studies confirm that there are no differences between conventional and distance education. ${ }^{10}$

\subsection{Methodology, hypothesis and the goal of the research}

The research presented in this paper aimed to explore the attitudes of attendants of the Jean Monnet Module LEULEX towards the efficiency of the applied methods and tools of distance learning in the implementation of the project. By using an anonymous questionnaire administered online, students were asked to express their opinions on the appropriateness and efficiency of online platforms (the application Zoom or blended learning) in the delivery of each course. The received data will be presented and analysed by using statistical methods. The results will give feedback to teachers and help them improve the teaching approach in the next project year. The hypothesis of the research is that most respondents will be satisfied with the distance teaching methods in the given circumstances. However, differences in results between specific courses are expected, which will indicate for which courses the online approach is more suitable than for others.

\section{FINDINGS}

72 respondents out of altogether 120 project participants participated in the survey on volontary basis and assessed the application of online teaching methods for every course. The questionnaire was administered in the Croatian language, but results presented in the form of graphics are clear due to the consistent use of colours denoting specific assessment levels. The answers assessing the efficiency of online teaching methods were the following: extremely successful /iznimno uspješno/ marked blue, optimal /optimalno/ - marked brown, satisfactory /zadovojavajuće/ - marked yellow, unsatisfactory /nezadovoljavajuće/ - marked green, and "I don't know" / "ne znam" - marked purple. The graphics are supplemented by students' comments that are chosen as representative for all the comments given for every subject.

10 Dudley-Evans; St John, op.cit., note 8 
Graphics 1. Legal Language and the EU

Nastava putem online platforme zoom u okviru ovog kolegija bila je:

71 odgovor

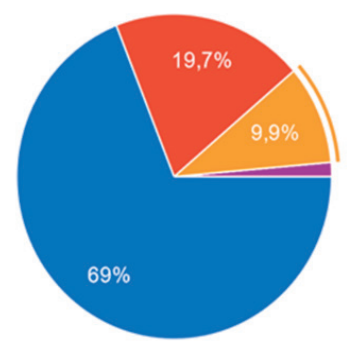

iznimno uspješna

optimalna

zadovoljavajuća

nezadovoljavajuća

ne znam

Comments: "Great professor with excellent skills! Lectures extremely interesting and useful!"

"Interesting lectures in a pleasant atmosphere; lectures were structured as an introduction to other courses within the project."

"All the professors have done their best in given conditions. I have learned a lot and gained new skills. I assess teaching by the online platform zoom as 'optimal' only because nothing can replace the face-to-face contact in teaching".

Graphics 2.: EU Law Terminology and Translation - English

Nastava putem online zoom platforme u okviru ovog kolegija bila je:

71 odgovor



iznimno uspješna

optimalna

zadovoljavajuća

nezadovoljavajuća

ne znam

Comments: "Excellent professor! Great and efficient lectures!"

"Very interesting lectures with lots of useful examples, but teaching face-to-face is always of a higher quality than teaching online." 
Graphics 3.: Introduction to EU Law Terminology - French

Nastava putem online zoom platforme u okviru ovog kolegija bila je:

72 odgovora
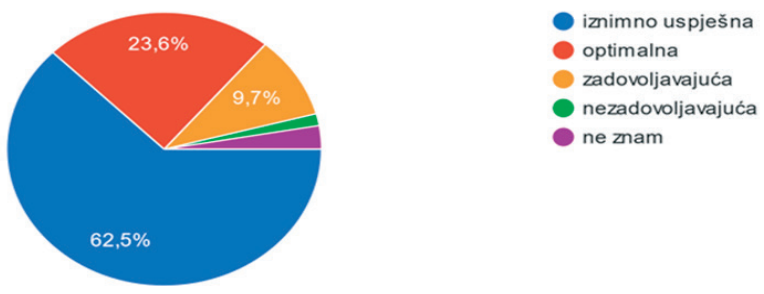

Comments: "Professor is an excellent expert, she invested a lot of effort and I admire her for successful combinations of different approaches in teaching students with different levels of knowledge. The approach face-to-face would have been better in those circumstances."

"Teaching approach could have been adapted more to us, total beginners in French."

"In some situations, using two screens by the professor would have been more efficient. And some materials presented were blurred."

Graphics 4: EU Law Terminology and Translation - German

Nastava putem online zoom platforme u okviru ovog kolegija bila je:

68 odgovora
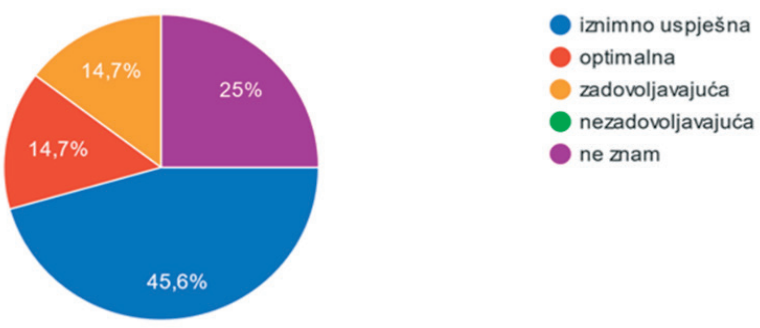

Comments: "It was interesting and I have learned a lot, though face-to-face teaching is always better than by using online platforms".

"I think that teaching approach should have been adapted to the beginners' level A1". "Sometimes it was difficult to follow all the tasks and advance through the course. In some cases, it would have been useful if we could have had two screens 
to fulfil the tasks properly”.

But also: "Zoom is an excellent platform for distance learning. It also enables interactive teaching and an efficient use of time".

Graphics 5: Basics of EU Law

Nastava putem online zoom platforme u okviru ovog kolegija bila je:

71 odgovor

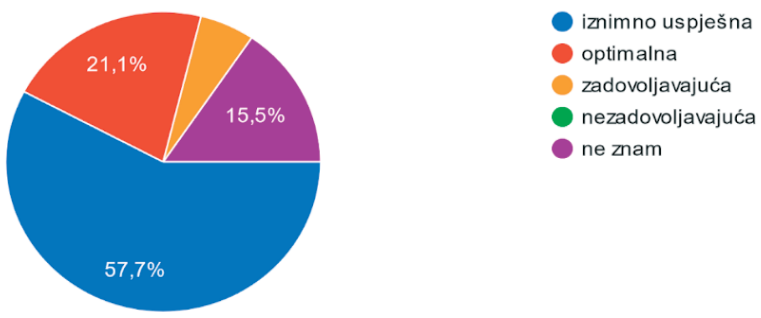

Comments: "The professors have done an excellent job, they are experienced teachers and experts in their field. Teaching face-to-face would have been an even better experience for us".

"I believe that activity and engagement of students would have been on a higher level if the lectures had been given face-to-face."

"The lectures were very successful, but as it was all theory, the results would have been the same no matter whether the lectures were online or face-to-face.

Graphics 6: Modern Translation Tools

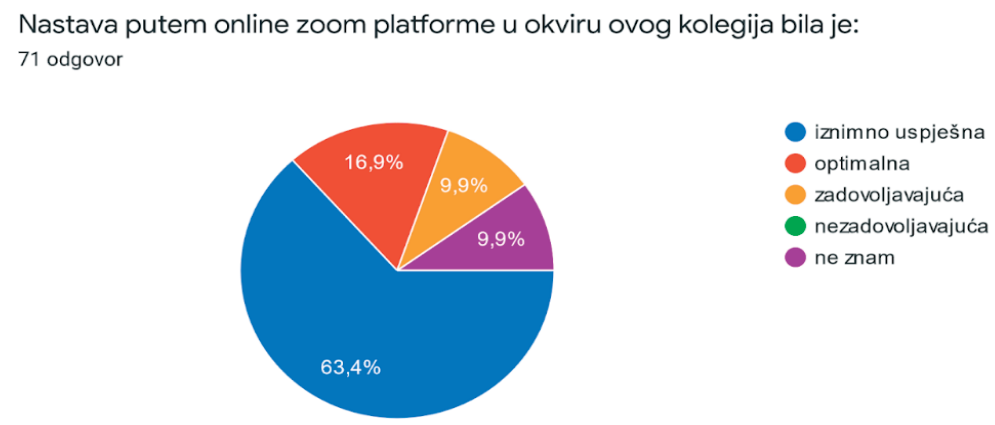

Comments: "The professor is an excellent teacher and professional. Excellent: both online and face-to-face." 
"In many situations, two screens had been necessary so that we could have followed all the examples and steps in the application of programmes".

"The only problem for me was the pace of advancement through the course. It was difficult for me to follow all the programmes, as I have seen them for the first time. Sometimes, the server was slowed down because many of us were using it at the same time and it caused difficulties in following all the tasks properly".

Graphics 7: Using Parallel Corpora in Translating EU Legislation

Nastava putem online zoom platforme u okviru ovog kolegija bila je:

72 odgovora

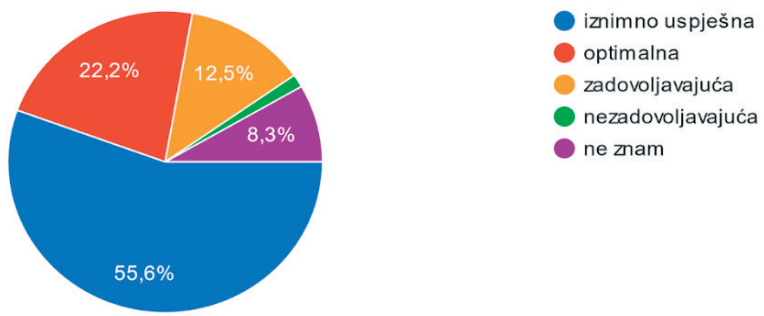

Comments: "The lectures were interesting and we learned a lot. It was awesome that all the time we were practicing the online sources and databases in 3 languages, and the professor was teaching the theory at the same time."

"For me, it was difficult to follow the lectures, I think I would have been more successful if the lectures had been face-to-face."

"In many situations, two screens were necessary so that we could follow the lectures and practice the application of parallel corpora available online". 
Graphics 8: Workshop Conference Interpreting

Nastava putem online zoom platforme u okviru ove radionice bila je:

70 odgovora

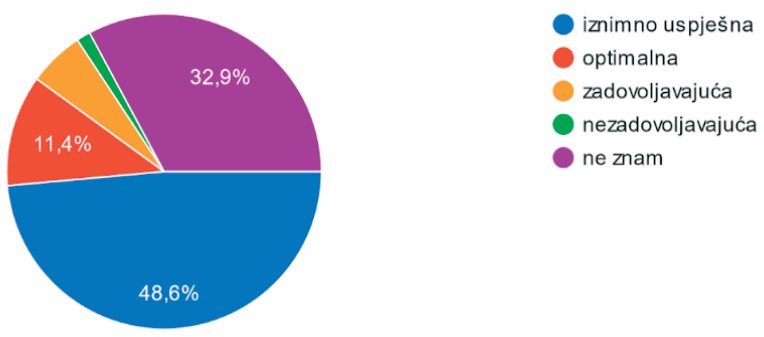

Comments: "A very useful and interesting workshop".

"It would have been better if we could have worked on the equipment normally. In the given circumstances, this experience will also be useful for us".

Graphics 9: Workshop Databases and Information on the EU

Nastava putem online zoom platforme u okviru ove radionice bila je:

69 odgovora

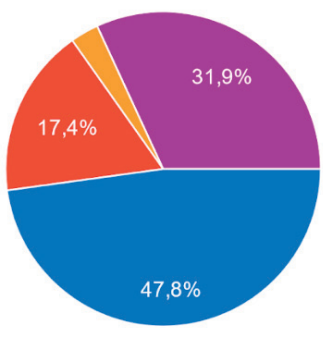

iznimno uspješna

optimalna

zadovoljavajuća

nezadovoljavajuća

ne znam

Comments: "Great workshop, very useful for my future work!"

"I think that this workshop is even more successful online than face-to-face because at the same time we could follow online the contents that the professor was speaking about". 
Graphics 10: Workshop Litigation before the CJEU

Nastava putem online zoom platforme u okviru ove radionice bila je:

71 odgovor

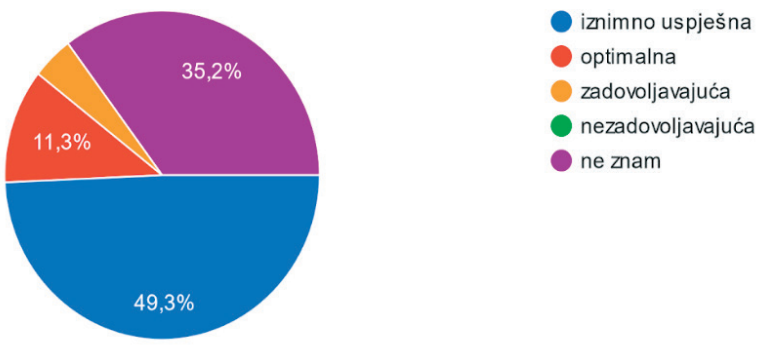

Comments: "The professor is a great professional and an expert in the field".

"The teaching was very successful. Because of the specific teaching contents, the results would be the same regardless whether presented online or by face-to-face approach."

\section{DISCUSSION}

Respondents' answers indicate that most of them were extremely satisfied with the digital platform applied in the implementation of the project activities in the conditions of the Covid-19 pandemic. The teaching approach in most courses was assessed as "extremely successful" by the majority of respondents - on average over $60 \%$. As for the workshops and the elective course in the German language, the majority of respondents gave the same answer, represented in these cases with a slightly lower percentage ranging between $45.6 \%-49.3 \%$. The reason for this slight difference is the fact that the course and the workshops are elective activities, so on average, $30 \%$ of respondents did not take the course/workshop. Another reason relating to the elective course EU Law Terminology and Translation - German was that the students taking the course mastered that language at different levels of knowledge - some mastered it at the B1 or even B2 levels, but some were beginners who have learned the language in primary school and forgotten most of that knowledge. For some of them, the pace of advancing through the course was too fast. Although most respondents assessed the teaching approach as extremely successful, their comments revealed that in most courses they would prefer a faceto-face approach. For the courses of theoretical character, they suggested that the same results would be achieved by using digital platforms online as by the conventional face-to-face teaching approach. 
As regards the online platforms applied in the implementation of the project activities as an answer to the changed conditions caused by the Covid-19 pandemic, we have been faced with different types of challenges: the uncertainty of whether the project will be carried out and how in given conditions, the need for a quick adjustment of teachers to new teaching conditions; constant changing of teaching approach depending on the situation; changes of the timetable because of isolation measures and professors' sick-leaves, etc.

On the other hand, the situation has resulted in some positive outcomes as well. Firstly, teachers have improved their skills in using digital technologies and have learned the benefits and shortcomings of using digital platforms in teaching their courses. The most striking benefit resulting from this situation is a great number of students from different parts of Croatia participating in the project (Zagreb, Samobor, Dubrovnik), including twelve young researchers and postgraduates from the universities in the wider region (Sarajevo, Zenica, Niš, Beograd, Skopje, Štip). It is for us to hope that the number of participants will not decrease after the pandemic when the project activities will be carried out almost exclusively face-to-face.

\section{CONCLUSIONS: BENEFITS AND SHORTCOMINGS OF PROJECT IMPLEMENTATION IN THE ERA OF PANDEMIC}

Electronic media represent an indispensable aid in the modern teaching process and have proved as very practical teaching tools in pandemic conditions when distance teaching had to be applied at all education levels. Pandemic has forced the teachers to learn how to use all the possibilities of ICT and online teaching tools and improve their skills in that field. The existence of those possibilities enabled the implementation of project activities in the Jean Monnet project LEULEX without any delays. Students' attitudes towards distance teaching methods in the implementation of the project are generally positive. However, their comments reveal that in most cases they would have preferred a face-to-face teaching approach. This especially refers to the courses that should be delivered by using specific equipment and licenced software. The intensive use of online teaching tools due to the Covid-19 pandemic seems to suit best to students from neighbouring countries or those living in far-away cities in Croatia. That is probably one of the reasons why we had such an impressive number of participants in the first project year. Students' answers shall serve as reliable databases indicating which teaching approach should be applied in the following project years to specific teaching activities. The analysis has shown that in normal circumstances, the teaching approach should be adjusted to a specific course, its contents, and 
the teaching equipment necessary for achieving the best results. It seems that the teaching model defined by American methodologists as "a teacher-focus blended model" seems to be the preferable model, as it encompasses both distance teaching methods and the face-to-face approach.

\section{REFERENCES}

\section{BOOKS AND ARTICLES}

1. Castro, R.: Blended learning in higher education: Trends and Capabilities, Education and Information Technologies (Springer), volume 24, 2019, pp. 2523-2546, https://doi. org/10.1007/s10639-019-09886-3

2. Dudeney, G.; Hockly, N. How to Teach English with Technology, Pearson, Essex, 2007

3. Dudley-Evans, T.; St John, M.J., Developments in English for Specific Purposes, Cambridge University Press, Cambridge, 2007

4. Gierke, O., Das bürgerliche Gesetzbuch und der deutsche Reichstag, Berlin, 1896

5. Ketterer, J.; Marsh, G.,. Re-Conceptualizing Intimacy and Distance in Instructional models, in: Online Journal of Distance Learning Administration, Volume IX, Number I. 2006, [https:// www.westga.edu/ -distance/ojdla/spring91/spring91.htm]

6. Kirchhof, P., Rechtsprechen ist mehr als Nachsprechen von Vorgeschriebenem, in: $\mathrm{Ha} \beta-\mathrm{Zum}-$ kehr, U. (eds.): Sprache und Recht, W. de Gruyter, Berlin - New York: 2001, pp.119-135

7. Larson, W. R.; Rusk, N.. Intrinsic Motivation and Positive Development, in:. Lerner, R. M.; Lerner, J. V.; Benson, J. (eds.), Advances in Child Development and Behavior, pp. 89-130, Academic Press, Burlington, 2011

8. Šarčević, S. (ed.), Legal Language in Action: Translation, Terminology, Drafting and Procedural Issues (9-21). Zagreb: Globus, 2009 